\title{
PREDYKCJA ZAGROŻENIA UPADLOŚCIĄ Z WYKORZYSTANIEM WYBRANYCH MODELI DYSKRYMINACYJNYCH NA PRZYKLADZIE POLREST S.A.
}

\section{Wstęp}

Przedsiębiorstwa funkcjonujące we współczesnej gospodarce rynkowej muszą uwzględniać zmieniające się otoczenie. Podążanie za zmianami otoczenia powinno być na stałe wpisane w działania zarządzających. To właśnie „w rękach” zarządzających znajduje się sukces jednostki, za który uznaje się utrzymywanie się tej jednostki w dobrej kondycji finansowej na rynku. Nie ulega również wątpliwości, że nieumiejętne zarządzanie może prowadzić do pogorszenia się sytuacji finansowej przedsiębiorstwa, a w długim okresie do bankructwa, czy upadłości ${ }^{1}$.

Celem artykułu jest przedstawienie na bazie studiów literaturowych wybranych modeli dyskryminacyjnych, umożliwiających zidentyfikowanie pierwszych symptomów zbliżającego się bankructwa. W części empirycznej artykułu została przedstawiona analiza przypadku, na przykładzie spółki PolRest, której celem jest sprawdzenie, czy zastosowanie modeli upadłościowych umożliwiłoby predykcję upadłości badanej spółki na tyle wcześnie, aby zapobiec temu zdarzeniu. Wybrana przez autorkę spółka jest w stanie upadłości i $\mathrm{z}$ tego powodu wydaje się, że jest ona odpowiednia do przeprowadzenia takiej analizy.

Tematyka artykułu wydaje się być istotna $\mathrm{z}$ punktu widzenia przyszłości polskiego rynku kapitałowego. Powszechne i systematyczne stosowanie modeli upadłościowych przez spółki może

\footnotetext{
Doktorantka, Instytut Ekonomii, Wydział Ekonomiczno-Socjologiczny, Uniwersytet Łódzki.

${ }^{1}$ Często terminy „bankructwo” i ,upadłość” traktowane są jako synonimy i używane zamiennie, co należy uznać za nieprawidłowe. Upadłość to kategoria $\mathrm{z}$ dziedziny prawa, natomiast bankructwo to termin ekonomiczny. Za bankructwo przedsiębiorstwa uważa się niepowodzenie w biznesie, jednak nie każda porażka prowadzi do sądowego postępowania upadłościowego. Zob. E. Mączyńska, Cykle życia i bankructwa przedsiębiorstw, Oficyna Wydawnicza Szkoła Główna Handlowa w Warszawie, Warszawa 2010, s. 20.
} 
umożliwić identyfikację niepokojących zmian $\mathrm{w}$ ich sytuacji finansowej na tyle wcześnie, aby móc zapobiec temu negatywnemu zjawisku.

\section{Predykcja zagrożenia upadłością przedsiębiorstwa}

Spółki funkcjonujące na rynku, ze względu na zmianę potrzeb konsumentów, ciągłe zmiany technologiczne, pojawienie się nowych produktów zastępujących stare itp., narażone są coraz częściej na rosnącą niepewność swojej dalszej egzystencji. Z tego powodu tworzenie długofalowej strategii korporacji jest niezwykle istotne, sprawia jednak coraz większe trudności. Niewłaściwie sformułowana strategia może w konsekwencji doprowadzić przedsiębiorstwo nawet do bankructwa, czy upadku.

Badania w obszarze prognozowania zagrożenia upadłością przedsiębiorstw zapoczątkowane zostały w Stanach Zjednoczonych przez E. I. Altmana w 1968 roku$^{2}$. W Europie, m.in. w Holandii, Niemczech i Francji, pierwsze badania zostały przeprowadzone w latach osiemdziesiątych ${ }^{3}$.

W Polsce w sposób kompleksowy problem dotyczący wykorzystania analizy dyskryminacyjnej do przewidywania problemów finansowych przedsiębiorstwa został podjęty przez J. Gajdkę i D. Stosa w 1996 roku $^{4}$. Należy jednak zauważyć, że szeroko zakrojone badania zostały podjęte W 1997 roku przez pracowników Instytutu Nauk Ekonomicznych $\mathrm{PAN}^{5}$. W ramach

\footnotetext{
2 J. B. Caouette, E. I. Altman, P. Narayanan, R. Nimmo, Managing Credit Risk: The Great Challenge for Global Financial Markets, John Wiley \& Sons, New Jersey 2011.

${ }^{3}$ B. Prusak, Nowoczesne metody prognozowania zagrożenia finansowego przedsiębiorstw, Difin, Warszawa 2005, s. 7.

${ }_{4}^{4}$ J. Gajdka, D. Stos, Wykorzystanie analizy dyskryminacyjnej w ocenie kondycji finansowej przedsiębiorstw, [w:] Borowiecki R. (red.), Restrukturyzacja w procesie przeksztatceń i rozwoju przedsiębiorstw, AE , Kraków 1996, s. 59-63. Warto zwrócić uwagę, że w Polsce modele wykorzystujące analizę dyskryminacyjną do przewidywania problemów finansowych przedsiębiorstw stworzyli również m.in.: A. Hołoda, B. Prusak, D. Appenzeller, K. Szarzec, D. Wierzba, D. Hadasik. Zob. T. Karol., B. Prusak, Upadtość przedsiębiorstw a wykorzystanie sztucznej inteligencji, CeDeWu Sp. z o.o., Warszawa 2005.

5 Projekt badawczy pt.: „Systemy wczesnego ostrzegania przed bankructwem przedsiębiorstw. Wskaźniki wczesnego ostrzegania" prowadzony pod
} 
projektu badawczego, kierowanego przez E. Mączyńską, zostały opracowane modele dyskryminacyjne bankructwa, które powstały w oparciu o zróżnicowaną liczbę (od 4 do 12) mierników finansowych ${ }^{6}$.

Autorzy, dokonując wyboru wskaźników zagrożenia upadłością, przyjęli założenie, iż pierwszymi przesłankami upadłości są ${ }^{7}$ :

- ujemna dynamika przychodów, aktywów i kapitału własnego,

- spadek zysków, występowanie strat i ujemny kapitał własny,

- wzrost zadłużenia oraz związanych z tym kosztów finansowych,

- pogarszanie się i utrata płynności finansowej,

- niski i obniżający się stopień wykorzystania zdolności produkcyjnych,

- pogarszanie się sprawności operacyjnej (spadek tempa rotacji składników majątkowych),

- zanikające lub nieefektywne inwestowanie w majątek trwały.

$\mathrm{Na}$ tej podstawie zostały wyselekcjonowane wskaźniki, które stanowiły charakterystyki pięciu następujących cech kondycji przedsiębiorstw: dynamiki (obrotów, aktywów i kapitału własnego), rentowności, zadłużenia, płynności i sprawności operacyjnej ${ }^{8}$.

Funkcja dyskryminacyjna (Z) obliczana jest jako suma iloczynów odpowiednich wskaźników informujących o kondycji badanego przedsiębiorstwa i stałych wag tych mierników. Dodatkowo wartość funkcji jest powiększona o stałą wartość $\mathrm{w}_{\mathrm{o}}{ }^{9}$. Funkcja zatem przyjmuje postać:

$$
\mathrm{Z}=\mathrm{w}_{1} * \mathrm{x}_{1}+\mathrm{w}_{2} * \mathrm{x}_{2}+\ldots \ldots+\mathrm{W}_{\mathrm{n}} * \mathrm{x}_{\mathrm{n}}+\mathrm{w}_{0}
$$

Wskaźniki znajdują się w tabeli 1.

kierunkiem E. Mączyńskiej. W pracach brali udział: M. Zawadzki, M. Żuchowski, J. Janek.

${ }^{6}$ E. Mączyńska, M. Zawadzki, Dyskryminacyjne modele predykcji bankructwa przedsiębiorstw, „Ekonomista”, nr 2, 2006, s. 225.

${ }^{7}$ Ibidem, s. 213-214.

${ }^{8}$ Ibidem, s. 214.

9 E. Mączyńska, Zagrożenie w działalności gospodarczej, Dylematy ustrojowo-strategiczne, [w:] Mączyńska E. (red.), Meandry upadtości przedsiębiorstw: klęska czy druga szansa?, Szkoła Główna Handlowa w Warszawie, Warszawa 2009, s. 61. 


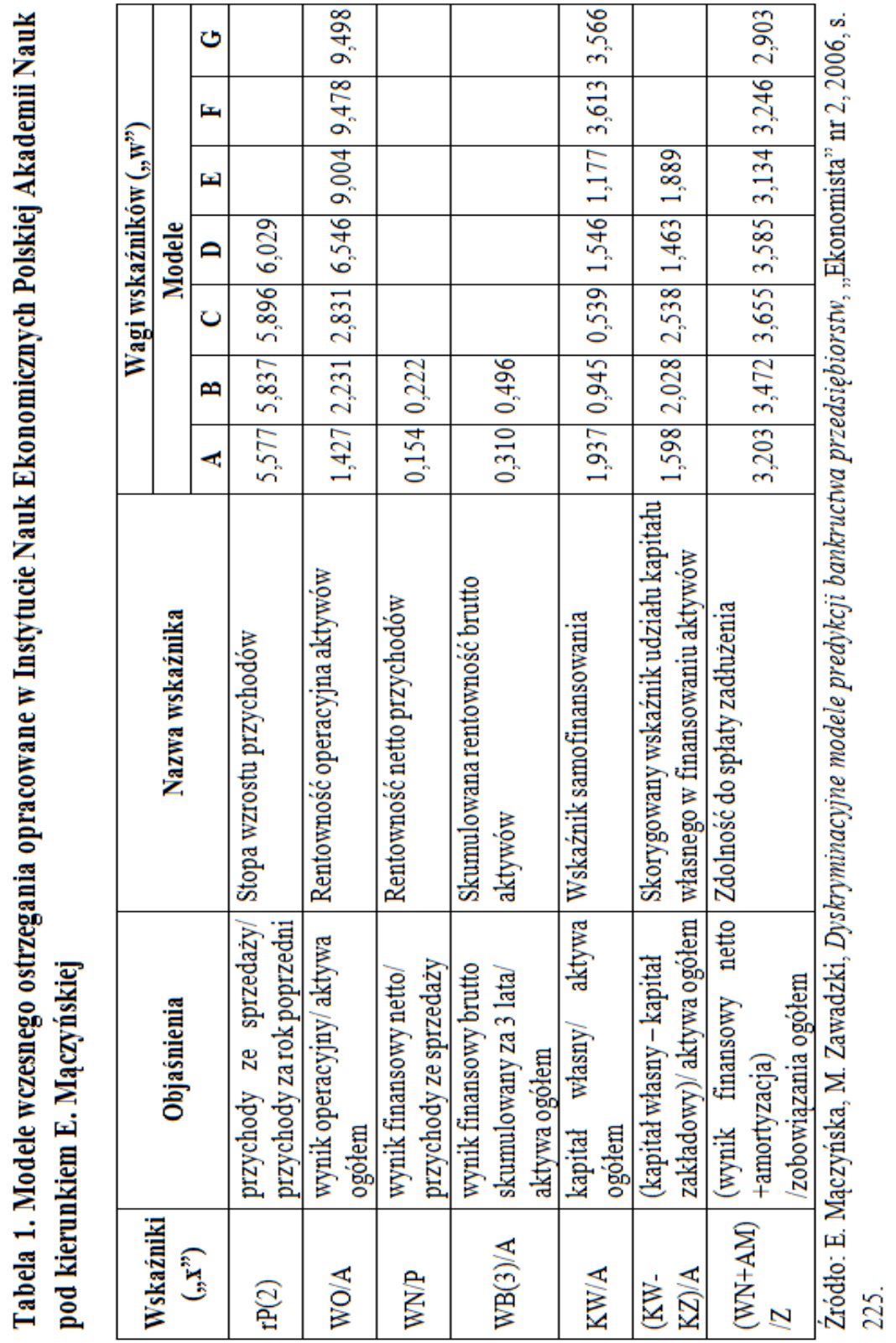




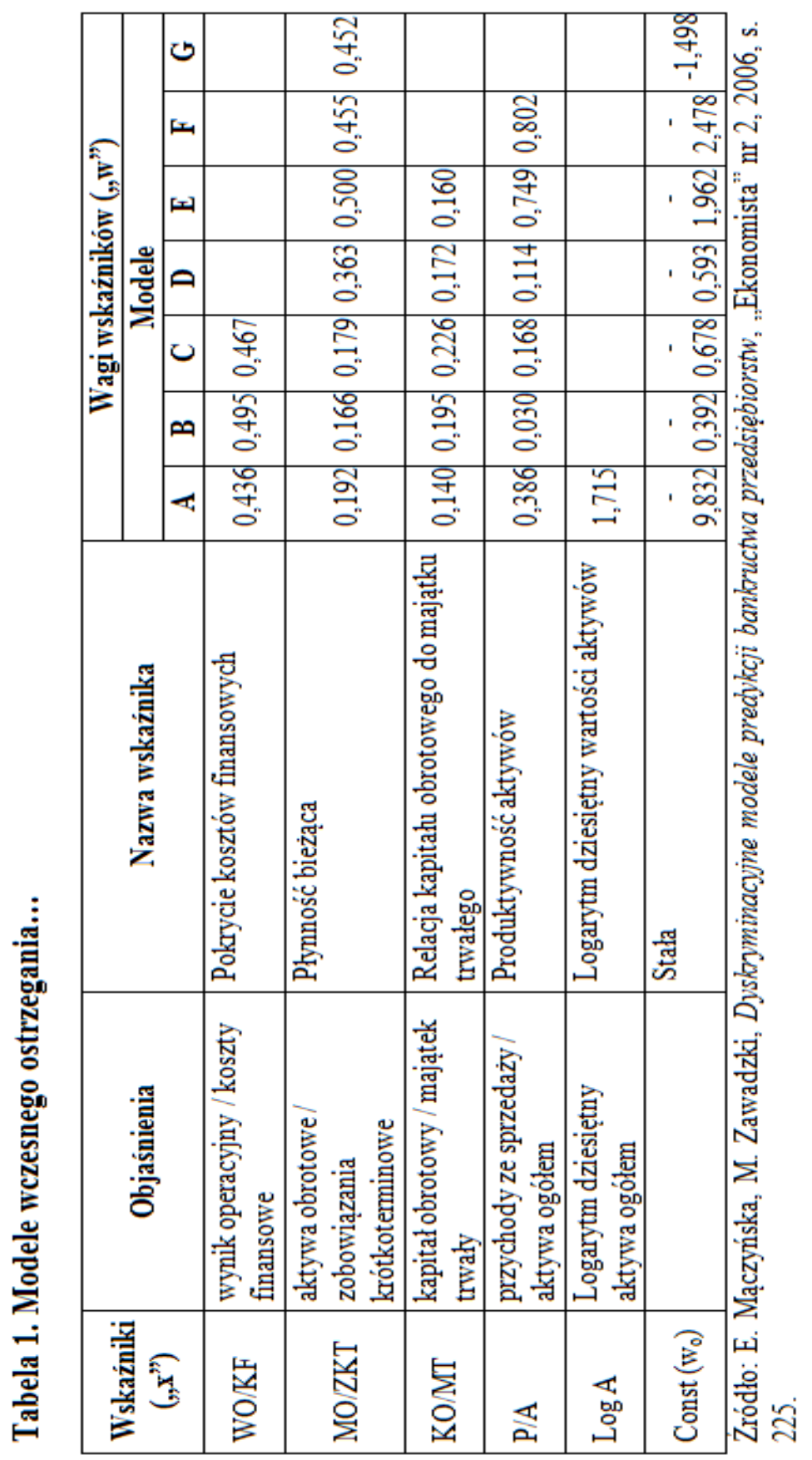


Wysoka wartość obliczonej funkcji dyskryminacyjnej oznacza, że spółka nie jest zagrożona upadłością. Gdy model prognozowania bankructwa przyjmuje wartości poniżej zera $(Z<0)$, jest to sygnał o złej kondycji przedsiębiorstwa i zagrożeniu upadłością. Funkcję można również wykorzystać do systematycznych analiz kondycji finansowej przedsiębiorstwa. Jeśli spada wielkość funkcji Z, oznacza to, iż sytuacja finansowa jednostki pogarsza się $e^{10}$.

Stworzone modele umożliwiają rozpoznanie wysyłanych przez przedsiębiorstwo symptomów upadłościowych nawet o 3-4 lata przed bankructwem. Zaproponowane modele identyfikują symptomy zagrożenia przedsiębiorstwa upadłością $\mathrm{z}$ dokładnością do około $90 \%{ }^{11}$.

Modele prognozowania zagrożenia finansowego spółki stanowią ważne narzędzie w predykcji upadłości przedsiębiorstwa. Różne podmioty mogą je wykorzystywać dla własnych celów, m.in. przy ${ }^{12}$ :

- analizie fuzji - w przypadku łączenia się przedsiębiorstw bądź w sytuacji przejęcia jednych korporacji przez inne, w rezultacie czego powstaje nowy podmiot - istotne jest zidentyfikowanie potencjalnych zagrożeń, związanych $\mathrm{z}$ połączeniem $\mathrm{z}$ innym podmiotem;

- gwarancji ubezpieczeniowej - wykorzystanie modelu do oceny potencjalnego ryzyka kredytowego oferowanego ubezpieczenia;

- nadzorze korporacyjnym - stosując modele dyskryminacyjne, rada nadzorcza i komitet ds. audytu mogą kontrolować kondycję finansową spółki i przewidywać upadłość przedsiębiorstwa;

- analizie inwestycji - potencjalni inwestorzy, w oparciu o wyniki modeli, mogą wybierać spółki, których sytuacja finansowa jest dobra i stabilna, aby ich decyzja inwestycyjna była zadowalająca;

- audycie - modele upadłościowe wskazują na możliwość wystąpienia problemów finansowych spółki, a w konsekwencji nawet upadłości;

- analizie kredytowej - banki i kredytodawcy mogą wykorzystać modele upadłościowe w celu zidentyfikowania spółek, w których występuje problem finansowy i niebezpieczeństwo upadłości.

\footnotetext{
${ }^{10}$ Ibidem, s. 61-62.
}

11 E. Mączyńska, Mikroekonomia - termometr dla gospodarki, www.portalwiedzy.pan.pl/images/stories/pliki/publikacje/academia/nr05/mac zynska.pdf, dostęp na 22.09.2011.

${ }^{12}$ J. K. Shim, J. G. Siegel, N. Dauber, Corporate controller's handbook of financial management 2008-2009, Wolters Kluwer Business, 2008, s. 60.0260.03 . 
Na potrzeby artykułu, autorka przedstawione powyżej modele predykcji bankructwa będzie rozpatrywała w odniesieniu do kształtowania się sytuacji finansowej spółki PolRest.

\section{Studium przypadku spólki PolRest}

Na podstawie raportów okresowych, raportów bieżących oraz informacji dostępnych na stronie internetowej spółki PolRest przygotowano studium przypadku. Dotyczy ono spółki, która jest w stanie upadłości likwidacyjnej. Badanie spółki obejmuje lata 20062010. Składa się ono z dwóch części: wstępnej analizy finansowej spółki oraz właściwej analizy finansowej, z wykorzystaniem modeli dyskryminacyjnych. Celem empirycznej części artykułu jest próba identyfikacji symptomów upadłości spółki PolRest, z wykorzystaniem przywołanych w literaturze modeli dyskryminacyjnych.

\subsection{Historia spólki PolRest}

PolRest rozpoczął swoją działalność w 1998 roku pod nazwą Korporacja Krakowska S.A. W 2002 roku nazwa ta została zmieniona na Gastropol S.A. i spółka rozpoczęła działalność gastronomiczną. W tym samym roku zanotowano wyraźny rozwój spółki (kupiła udziały w firmie Dom Restauracyjny, dodatkowo przejęła 5 lokali gastronomicznych w Krakowie i Zakopanem). Od 2006 roku spółka funkcjonowała jako PolRest S.A. ${ }^{13}$.

Rok 2007 okazał się przełomowym dla tej spółki, ponieważ zadebiutowała ona na rynku podstawowym Giełdy Papierów Wartościowych w Warszawie. Akcje spółki cieszyły się dużym powodzeniem, gdyż wielkość sprzedaży z roku na rok rosła w szybkim tempie, a dodatkowo rentowność spółki wynosiła około 10\%. Spółka nie miała problemów ze znalezieniem nabywców. „Do obrotu giełdowego wprowadzono 1250000 praw do akcji zwykłych serii C (...). Cena emisyjna akcji w ofercie publicznej wynosiła 20,00 zł. Kurs otwarcia notowań PDA (praw do akcji) w dniu debiutu wyniósł 24,50 zł, tj. o 22,5\% wyżej niż w ofercie publicznej. Na koniec dnia kurs zwyżkował do 26,00 zł (wzrost o 30\%)" ${ }^{\text {"14 }}$. Powiększenie kapitału miało umożliwić zwiększenie liczby restauracji. W kolejnych miesiącach kurs akcji zaczął spadać. Nie pojawiały się jednak żadne niepokojące informacje ze spółki, zatem spadek był związany

\footnotetext{
${ }^{13}$ www.PolRest.pl/pl/firma/historia, dostęp na 20.01.2012.

14 www.PolRest.pl/pl/dla_ inwestorow/historia_operacji_na_akcjach, dostęp na 20.01.2012.
} 
z ogólnym spadkiem notowań na giełdzie papierów wartościowych. PolRest nabywał nowe lokale i rozszerzał swoją działalność. Niespodziewanie, 6 lipca 2010 roku, PolRest poinformował, że Deutsche Bank PBC złożył wniosek o ogłoszenie upadłości spółki. 16 grudnia tego samego roku krakowski sąd wydał postanowienie o ogłoszeniu upadłości likwidacyjnej PolRestu.

\subsection{Sytuacja finansowa spółki PolRest}

Dokonując wstępnej analizy sytuacji finansowej spółki PolRest, warto spojrzeć na kształtowanie się podstawowych danych finansowych, pochodzących ze sprawozdań finansowych, które przedstawia tabela 2 .

Tabela 2. Wybrane dane finansowe dla PolRest w latach 20062010 (w tys zl)

\begin{tabular}{|l|c|r|r|r|r|}
\hline Dane finansowe & $\mathbf{2 0 0 6}$ & $\mathbf{2 0 0 7}$ & $\mathbf{2 0 0 8}$ & $\mathbf{2 0 0 9}$ & $\mathbf{2 0 1 0}$ \\
\hline Przychody ze sprzedaży & 29442 & 38789 & 42816 & 30823 & 328 \\
\hline $\begin{array}{l}\text { Zysk/strata z } \\
\text { działalności operacyjnej }\end{array}$ & 4320 & 4910 & -4649 & $\begin{array}{r}- \\
27440\end{array}$ & 3306 \\
\hline \begin{tabular}{l} 
Zysk netto \\
\hline $\begin{array}{l}\text { Przepływy pieniężne } \\
\text { netto z działalności } \\
\text { operacyjnej }\end{array}$
\end{tabular} & 2769 & 3883 & -1874 & 42824 & -7198 \\
\hline $\begin{array}{l}\text { Przepływy pieniężne } \\
\text { netto z działalności } \\
\text { inwestycyjnej }\end{array}$ & -5010 & 15757 & 12182 & 4537 & $*$ \\
\hline $\begin{array}{l}\text { Przepływy pieniężne } \\
\text { netto z działalności } \\
\text { finansowej }\end{array}$ & 5042 & 19731 & 14003 & -3297 & $*$ \\
\hline $\begin{array}{l}\text { Przepływy pieniężne } \\
\text { netto razem }\end{array}$ & 2831 & 2475 & -4652 & -836 & $*$ \\
\hline \begin{tabular}{l} 
Aktywa \\
\hline Kapitał własny
\end{tabular} & 9062 & 36885 & 35011 & -2076 & $*$ \\
\hline Kapitał zakładowy & 500 & 625 & 625 & 625 & -25510 \\
\hline
\end{tabular}

*Spółka nie ujawniała informacji na temat przepływów pieniężnych w raporcie rocznym za 2010 rok.

Źródło: opracowanie własne na podstawie sprawozdań finansowych spółki PolRest za okres 2006-2010. 
Analizując wartość przychodów ze sprzedaży produktów, towarów i materiałów, można dostrzec regularny wzrost tych wielkości z roku na rok w latach 2006-2008. W kolejnych latach wartość przychodów spadała. Przychody w roku 2009 zmniejszyły się o niemal 1/3 w stosunku do roku 2008.

Działalność operacyjna jest podstawową działalnością każdego przedsiębiorstwa, ponieważ obejmuje ona, m.in.: procesy produkcyjne, wytwarzanie usług, czy działalność handlową. Spółka PolRest posiadała dodatni wynik operacyjny w 2006 i 2007 roku, co należy interpretować pozytywnie. Sytuacja ta uległa jednak zmianie w kolejnych latach. W 2008 i 2009 roku analizowana spółka wygenerowała stratę $\mathrm{z}$ tego rodzaju działalności, co świadczy o nieefektywności działalności operacyjnej przedsiębiorstwa. W 2010 roku obserwowano dodatnią wartość, która wynikała przede wszystkim z generowania pozostałych przychodów operacyjnych, co wynikało, m.in. ze zbycia niefinansowych aktywów trwałych.

Warto również zwrócić uwagę na generowane przez spółkę przepływy pieniężne. W 2006 roku spółka posiadała dodatnie przepływy z działalności operacyjnej i finansowej, natomiast ujemne z działalności inwestycyjnej. Jest to sytuacja typowa dla spółki, która rozwijała się i poszerzała swoją działalność. Spółka, pomimo posiadania dodatniego strumienia operacyjnego, nie była $\mathrm{w}$ stanie pokryć wydatków związanych $\mathrm{z}$ inwestycjami. $\mathrm{Z}$ tej też przyczyny wspomagała się źródłami zewnętrznymi (m.in. kredytami) i stąd dodatnie saldo $\mathrm{z}$ działalności finansowej. W 2007 roku nastąpiła zmiana strumienia $\mathrm{z}$ działalności operacyjnej na wartość ujemną. Zarówno w 2007, jak i 2008 roku spółka generowała nadwyżkę pieniężną tylko z działalności finansowej. W kolejnym roku sytuacja spółki uległa zmianie. Saldo działalności finansowej przyjęło wartość ujemną, a przepływy pieniężne $\mathrm{z}$ działalności inwestycyjnej miały saldo dodatnie. Ujemny strumień operacyjny i finansowy był finansowany sprzedażą części aktywów spółki. Podmiot gospodarczy, sprzedając elementy majątku trwałego, chciał w ten sposób pokryć niedobór środków pieniężnych.

Ponadto istotna jest relacja zachodząca pomiędzy wynikiem finansowym netto a kierunkiem przepływów środków pieniężnych z działalności operacyjnej. W 2006 roku spółka generowała zarówno zysk netto, jak i dodatnie przepływy. Sytuacja ta zmieniła się w kolejnym roku i spółka, mimo iż osiągała zyski, to miała niedobór środków pieniężnych $\mathrm{z}$ tej działalności i posiadała problemy z utrzymaniem płynności finansowej. W 2008 roku spółka poniosła stratę netto. Taka sytuacja miała również miejsce w roku 2009. 
Uzyskane wyniki świadczyły o problemach finansowych spółki, które znalazły odzwierciedlenie w stracie netto i braku środków pieniężnych.

Istotna, z punktu widzenia analizy, jest również suma bilansowa. Wartość aktywów w latach 2006-2008 zwiększała się z roku na rok, co należy interpretować pozytywnie, ponieważ świadczy o wzroście przedsiębiorstwa. Z kolei 2009 rok związany był ze zmniejszeniem sumy bilansowej, głównie za sprawą sprzedaży majątku trwałego.

Zaangażowanie właścicieli $w$ spółkę miało swoje odzwierciedlenie w wielkości kapitałów własnych. W analizowanej spółce wartość tej pozycji bilansowej wzrastała i miała wartość dodatnią. Niestety ta sytuacja zmieniła się w 2009 roku, kiedy kapitał własny przedsiębiorstwa był ujemny, co było spowodowane przede wszystkim ujemnym wynikiem finansowym netto. Warto również zwrócić uwagę, iż spółka PolRest w 2007 roku postanowiła zwiększyć wielkość kapitału zakładowego o 125 tys. zł poprzez emisję akcji.

Podsumowując, sytuację finansową spółki PolRest w latach 2006-2007 można było odbierać pozytywnie. Jedynym niepokojącym sygnałem było generowanie ujemnych przepływów pieniężnych z działalności operacyjnej w roku 2007. Sytuacja jednak pogorszyła się w 2008 roku, kiedy spółka poniosła stratę z działalności podstawowej. W kolejnym roku strata ta powiększyła się, a spółka zaczynała wyprzedawać swój majątek. Kształtowanie się poszczególnych danych finansowych spółki PolRest, począwszy od roku 2008 wskazuje, że spółka zbliżała się do upadłości.

\subsection{Sytuacja spółki w świetle modeli upadłościowych}

Kondycja finansowa spółki PolRest została zbadana z wykorzystaniem modeli dyskryminacyjnych, zaproponowanych przez zespół E. Mączyńskiej, które zostały przedstawione w części teoretycznej artykułu. Wybór powyższych modeli uzasadniony jest faktem, iż badania $\mathrm{w}$ instytucie PAN były prowadzone na szeroką skalę, a prawdopodobieństwo identyfikacji upadłości przedsiębiorstwa z wykorzystaniem modeli M. Mączyńskiej było wysokie i wynosiło około $90 \%{ }^{15}$. Jakość wybranych modeli prognozowania bankructwa jest zatem wysoka. Obliczone wartości wykorzystanej funkcji znajdują się w tabeli 3 .

15 E. Mączyńska, Mikroekonomia - termometr dla gospodarki, www.portalwiedzy.pan.pl/images/stories/pliki/publikacje/academia/nr05/mac zynska.pdf, dostęp na 22.09.2011. 
Tabela 3. Modele wczesnego ostrzegania przed upadłością dla PolRest w latach 2006-2010

\begin{tabular}{|l|r|r|r|r|r|r|r|}
\hline Rok & $\begin{array}{c}\text { Model_ } \\
\text { A }\end{array}$ & $\begin{array}{c}\text { Model_ } \\
\text { B }\end{array}$ & $\begin{array}{c}\text { Model_ } \\
\text { C }\end{array}$ & $\begin{array}{c}\text { Model } \\
\text { D }\end{array}$ & $\begin{array}{c}\text { Model_ } \\
\text { E }\end{array}$ & $\begin{array}{c}\text { Model_ } \\
\text { F }\end{array}$ & $\begin{array}{c}\text { Model_ } \\
\text { G }\end{array}$ \\
\hline 2006 & 12,80 & 15,27 & 15,07 & 12,90 & 4,17 & 4,06 & 3,76 \\
\hline 2007 & 95,06 & 107,50 & 102,38 & 15,82 & 7,92 & 7,44 & 7,43 \\
\hline 2008 & $-499,31$ & $-567,03$ & $-534,59$ & 8,53 & 1,19 & 0,85 & 1,18 \\
\hline 2009 & $-24,75$ & $-26,99$ & $-26,83$ & $-24,89$ & $-34,65$ & $-36,36$ & $-37,27$ \\
\hline 2010 & $-48,22$ & $-20,94$ & $-5,44$ & $-17,21$ & $-2,82$ & $-56,96$ & $-55,00$ \\
\hline
\end{tabular}

Źródło: opracowanie własne.

Wyniki wskazują, iż wskaźniki predykcji bankructwa w latach 2006-2007 kształtowały się na poziomie niewskazującym zagrożenia upadłością, gdyż były dodatnie, co jest zgodne $\mathrm{z}$ wcześniej przedstawioną sytuacją finansową spółki. Jednakże wartości tych wskaźników zmieniły się od 2008 roku. Funkcje dyskryminacyjne Modeli A, B i C przyjęły wartości ujemne, a dodatkowo wartości Modeli E, F i G kształtowały się blisko zera. Takie wyniki wskazują na istotne zagrożenie upadłością. W kolejnych latach wartości wszystkich oszacowanych modeli potwierdziły złą sytuację badanej spółki. Z przeprowadzonej analizy wynika, że powyższe modele wykazały rosnące zagrożenie upadłością badanej spółki PolRest, które pojawiło się już w 2008 roku.

\section{Podsumowanie}

Bankructwo jest naturalnym elementem gospodarki wolnokonkurencyjnej, jest jednocześnie narzędziem eliminowania jednostek niebędących w stanie sprostać konkurencji rynkowej. Często wynika to ze złego zarządzania - zarówno strategicznego, jak i operacyjnego. Jednocześnie należy pamiętać, że dobór strategii nie jest zadaniem łatwym, zwłaszcza we współczesnej rzeczywistości gospodarczej, w której jedyną pewną rzeczą jest zmiana. Bankructwo związane jest $\mathrm{z}$ procesem pogarszania się sytuacji finansowej na przestrzeni lat. Innymi słowy, jednostki nie bankrutują z dnia na dzień. Ważne jest, aby zidentyfikować pierwsze symptomy zbliżającego się bankructwa. W tym zakresie wartościowe są prezentowane w literaturze modele dyskryminacyjne.

W artykule został podjęty problem dotyczący wysyłanych symptomów upadłościowych, umożliwiających predykcję bankructwa. $\mathrm{Na}$ podstawie przeprowadzonej analizy przypadku zarówno analiza sytuacji finansowej spółki, jak i modele dyskryminacyjne predykcji 
bankructwa potwierdziły, że od 2008 roku można było zaobserwować problemy finansowe spółki.

Podjęty problem wydaje się być ważny i aktualny. Co więcej, nie straci on na znaczeniu w przyszłości, gdyż rosnąca konkurencja zwiększy tylko ryzyko upadłości, czy bankructwa.

\section{Bibliografia}

1. Caouette J. B., Altman E. I., Narayanan P., Nimmo R., Managing Credit Risk: The Great Challenge for Global Financial Markets, John Wiley \& Sons, New Jersey 2011.

2. Gajdka J., Stos D., Wykorzystanie analizy dyskryminacyjnej w ocenie kondycji finansowej przedsiębiorstw, [w:] Borowiecki R. (red.), Restrukturyzacja $w$ procesie przekształceń $i$ rozwoju przedsiębiorstw, AE, Kraków 1996.

3. Karol T., Prusak B., Upadtość przedsiębiorstw a wykorzystanie sztucznej inteligencji, CeDeWu Sp. z o.o., Warszawa 2005.

4. Mączyńska E., Cykle życia i bankructwa przedsiębiorstw, Oficyna Wydawnicza Szkoła Główna Handlowa w Warszawie, Warszawa 2010.

5. Mączyńska E., Mikroekonomia - termometr dla gospodarki, www.portalwiedzy.pan.pl/images/stories/pliki/publikacje/academi a/nr05/maczynska.pdf.

6. Mączyńska E., Zagrożenie w działalności gospodarczej, Dylematy ustrojowo-strategiczne, [w:] Mączyńska E. (red.), Meandry upadłości przedsiębiorstw: klęska czy druga szansa?, Szkoła Główna Handlowa w Warszawie, Warszawa 2009.

7. Mączyńska E., Zawadzki M., Dyskryminacyjne modele predykcji bankructwa przedsiębiorstw, „Ekonomista”, nr 2, 2006.

8. Prusak B., Nowoczesne metody prognozowania zagrożenia finansowego przedsiębiorstw, Difin, Warszawa 2005.

9. Shim J. K., Siegel J. G., Dauber N., Corporate controller's handbook of financial management 2008-2009, Wolters Kluwer Business, 2008.

10. www.PolRest.pl.

\section{Streszczenie}

Modele dyskryminacyjne są przydatnym narzędziem pozwalającym na przewidywanie bankrutctwa przedsiębiorstw. Zagadnienie to jest o tyle ważne, że finansowe modele predykcji ryzyka finansowego są używane również $\mathrm{w}$ analizie fuzji, ładu korporacyjnego, analizach inwestycyjnych, badaniach audytowych, czy podczas nadawania ocen wiarygodności 
kredytowej. W artykule dokonano przeglądu literatury przedmiotu, by zaprezentować wybrane modele dyskryminacyjne. W części empirycznej pracy zbadano i oceniono wartość prognostyczną wybranych modeli dyskryminacyjnych na przykładzie PolRest S.A.

\section{Summary}

\section{PREDICTION FOR RISK OF BANKRUPTCY WITH THE USE OF SELECTED DISCRIMINATION MODELS - THE EXAMPLE OF POLREST S.A.}

Discrimination models are an important tool for predicting the bankruptcy of enterprises. This issue is all the more important because of the fact that the financial risk prediction models are also used for: examining mergers, warranty insurances, corporate governance, investment analysis, analysis of audit or credit examination. The article is based on literature studies and presents selected discrimination models. The empirical part of the article presents the PolRest S.A. case study aimed to test the effectiveness of bankruptcy prediction with the use of discrimination models. 